\title{
8.9 Формування поліпредметних навчальних компетенцій на основі інтеграції предметів природничого циклу
}

Природничий цикл включає систему наук про природу: фізику, хімію, біологію, географію, астрономію, екологію. В контексті даної праці, розглядаються такі науки як фізика, хімія та біологія. Кожна 3 цих наук має свій предметний зміст, структуру, методи дослідження, описує якусь одну сторону природи, будує її модель. Вивчаючи одну з цих наук, не можна забувати, що світ цілісний і єдиний.

В загальноосвітній школі предмети природничого циклу покликані розкрити перед учням сучасну наукову картину світу. Знання про природу становлять природничо-науковий фундамент світогляду сучасної людини. Таким чином, кожен момент отримання знань повинен бути одночасно i формуванням цілісності свідомості учня, єдиної системи знань про природу - iї інтегрального образу.

При осягненні великої правди природи, учні відчувають об'ємність недостатньо систематизованих знань про неї. Вирішити цю проблему дозволяє інтеграція предметів. Однією 3 форм реалізації інтегрованого підходу до навчання $є$ встановлення міжпредметних зв'язків на уроках природничого циклу (фізики, хімії та біології). Вони грають важливу роль в підвищенні практичної і науково-теоретичної підготовки учнів, істотною особливістю якої є оволодіння здобувачами освіти узагальненим характером пізнавальної діяльності. Інтегрований характер одержуваних знань дає можливість застосовувати їх в конкретних ситуаціях, при розгляді приватних питань, як у навчальній, так і в позаурочній діяльності, у майбутноьму виробничому, науковому та суспільному житті випускників закладів загальної середньої освіти.

У професійній діяльності вчителя завжди $є$ простір для пошуку, педагогічної творчості на рівні інтеграції знань 3 предметів.

Так як інтеграція - це не самоціль, а певна система у діяльності вчителя, то вона повинна вирішувати певні завдання інтегрованого навчання: 
- підвищувати рівень знань учнів з предмета, який проявляється в глибині засвоюваних понять, закономірностей за рахунок їх багатогранної інтерпретації з використанням відомостей наук, що інтегруються;

- змінювати рівень інтелектуальної діяльності, шляхом розгляду навчального матеріалу з позиції провідних ідей, встановленням природних взаємозв'язків між досліджуваними проблемами;

- підвищувати пізнавальний інтерес учнів, що проявляється в бажанні активної і самостійної роботи на уроці та у позаурочний час;

- включати учнів у творчу діяльність.

У класичній педагогіці ідея міжпредметних, інтеграційних зв'язків народилася в ході пошуку шляхів відображення цілісності природи в змісті навчального матеріалу. Все, що знаходиться у взаємному зв'язку, повинно викладатися в такому ж зв'язку, вважав Я.А. Коменський. Він розумів, наскільки важливо встановлювати зв'язки між предметами для формування системи знань в учнів і забезпечення цілісності процесу навчання.

І.Г. Песталоцці розкрив різноманіття взаємозв'язків навчальних предметів. Він виходив 3 вимоги: «Приведи в своїй свідомості всі по суті взаємопов'язані між собою предмети в той самий зв'язок, в якому вони знаходяться у природі».

Найбільш повне психолого-педагогічне обгрунтування дидактичної значущості міжпредметних зв'язків дав К.Д. Ушинський. У книзі «Людина як предмет виховання» він виводить їх 3 різних асоціативних зв'язків, що відображають об'єктивні взаємозв'язки предметів і явищ. У його теорії ідея міжпредметних зв'язків виступає як частина проблеми системності навчання.

В даний час виділяють декілька можливих моделей формування навчальних компетенцій на основі інтеграції предметів природничого циклу:

1. Створення курсу, що об'єднує кілька предметів з однієї освітньої галузі. При цьому питома вага змісту різних предметів однакова, a їх взаємопроникнення виводить зміст на якісно новий рівень.

2. Об'єднання навчальних предметів з однієї освітньої галузі або блоку на базі переважно однієї дисципліни. 
3. Можливо поєднання різних, але близьких освітніх областей, які виступають на рівних, а також предметів близьких освітніх областей, де один 3 них зберігає предметну специфіку, а інші виступають в якості допоміжної основи.

4. У варіативній частині навчального процесу можливе створення інтегрованих курсів, в яких об'єднуються предмети 3 віддалених освітніх областей.

5. Загальноосвітній зміст переломлюється через профільну специфіку, яка представлена, наприклад, в курсах типу «Хімія і медицина», «Фізика i економіка»,«Прикладна хімія», « Біофізика», «Біохімія» та ін.

6. Можлива інтеграція, при якій подальша тема випливає 3 попередньої.

Педагогічні умови формування поліпредметних навчальних компетенцій можуть формуватися i здійснюватися на будь-якому уроці або етапі педагогічного процесу на основі інтеграції:

- $\quad$ на рівні педагогічних цілей (орієнтація на такі інтегральні властивості і характеристики особистості, як активність, самостійність, креативність);

- $\quad$ на рівні змісту (інтегрована програма, інтегровані навчальні курси);

- $\quad$ на рівні сфер активності школярів (інтегровані уроки, екскурсії, конференції, проекти);

- $\quad$ на рівні педагогічних технологій (варіативність інтеграційних форм і методів педагогічного впливу).

В сучасній школі 3 метою формування навчальних компетенцій як науково-методичної основи виділяють кілька рівнів інтеграції.

Перший рівень - інтеграція природничо-наукових та гуманітарних предметів. Важлива інтеграція цих навчальних дисциплін, пошук в їх взаємодії і натхнення нових підходів до цілісного бачення світу, для розкриття духовного потенціалу предметів.

Другий рівень - інтеграція дисциплін на основі розробки вчителями єдиних програм для формування провідних понять межпредметного, метапредметного 
характеру в процесі навчання. Така робота може бути здійснена на основі виділення головних освітніх ліній навчальних предметів.

Третій рівень - інтеграція за рахунок здійснення і посилення практичної спрямованості не тільки конкретного предмета, а й циклу предметів на основі реалізації горизонтальних взаємозв'язків навчальних дисциплін. Крім предметно-специфічних і практико- інтегрованих навчальних завдань, вельми актуальним є створення умов для освоєння учнями моральних, духовноморальних, патріотичних, соціально-економічних основ людського життя i діяльності на основі краєзнавчого підходу, що має стати одним із головних завдань школи. Це передбачає широке звернення вчителя безпосередньо до суб'єктного досвіду учнів і його осмислення.

Четвертий рівень - використання загальнонаукових методів пізнання, навчання цим методам учнів. Відомо, що до наукових методів пізнання, перш за все, відносяться: досвід, спостереження, гіпотеза, експеримент .

Орієнтація педагогічних колективів шкіл на структурування змісту освіти за рівнями, відповідно до методології наукового пізнання дозволить не тільки здійснити інтеграцію змісту навчального матеріалу всіх шкільних предметів, природничо-наукових в тому числі, але i:

1) раціонально скоротити обсяг інформації, пропонованої школярам;

2) більш чітко здійснити систематизацію досліджуваного навчального матеріалу;

3) створити у дітей більш повні уявлення про цілісну природничу картину світу.

У зв'язку з цим, через великий обсяг навчальної інформації з предметів, важливим стає включення учителем в план навчальних занять питань розвитку у школярів умінь і навичок використання наукових методів пізнання, вивчення технологій науково обгрунтованої організації навчальної праці з метою більш ефективного та комплексного освоєння навчального змісту.

Яким чином можливо здійснювати інтеграційний підхід в сучасній школі? Існуюча предметна система навчання відображає традиційно створившийся в 
науці поділ предметних областей знань на природні, технічні, гуманітарні. У світовій науковій педагогіці до сих пір йде дискусія з питання про те, як будувати навчальні плани і як проводити інтегровані уроки. На сьогоднішній день пропонується інтегрована побудова навчального процесу, зі збереженням предметами свого «предметного обличчя». Курс на варіативність, передбачений навчальним планом, створює для цього сприятливі умови. Можлива тематична, проектна інтеграція декількох предметів при вивченні окремих тем. Результативними $\epsilon$ інтегровані курси, які $\epsilon$ автономними науковими дисциплінами зі своїм специфічними об'єктами вивчення, включають в себе елементи різних дисциплін, що розглядаються комплексно і якісно. Інтегрований урок - якісно особливий тип уроку, що об'єднує в собі навчання і навчальну взаємодію одночасно по декількох дисциплінах при вивченні однієї теми або явища, процесу. До використання інтегрованих підходів учителя, нажаль вдаються не часто і головним чином в наступних випадках:

1) при виявленні дублювання одного і того ж матеріалу в навчальних програмах і підручниках;

2) при ліміті часу на вивчення теми і бажання скористатися готовим змістом з паралельної дисципліни;

3) при вивченні міжнаукових і узагальнених категорій (рух, час, розвиток, величина і інші), законів, принципів, що охоплюють різні аспекти людського життя і діяльності;

4) при виявленні протиріч в описі і трактуванні одних і тих же явищ, подій, фактів у різних науках;

5) при демонстрації більш широкого поля прояви досліджуваного явища, що виходить за рамки досліджуваного предмета;

6) при створенні проблемної, розвиваючої методики навчання предмету.

Переваги багатопредметного інтегративного уроку перед традиційним монопредметним очевидні:

- $\quad$ на такому уроці можна створити більш сприятливі умови для розвитку найрізноманітніших інтелектуальних якостей учнів; 
- через нього можна вийти на формування в учнів старших класів ширшого науково-теоретичного i науково-практичного мислення, розвиток кругозору, застосування теоретичних знань в практичному житті, в конкретних життєвих, професійних і наукових ситуаціях;

- інтегративні уроки наближають процес навчання до життя, натуралізують його, оживляють духом часу, наповнюють смислами;

- інтегровані уроки допомагають учням знайти i осягнути єдині закономірності різних наук, ефективно формують природничий світогляд;

- ці уроки взаємозбагачують учителів, зближують їх, сприяють поліпшенню психологічного мікроклімату в колективі і творчому росту.

Інтегративне завдання - різновид навчальних завдань, яке може застосовуватися на різних уроках. Їх особливість полягає в синтезі знань і умінь 3 різних наук, різних навчальних дисциплін, тем, проблем, в об'єднанні їх навколо і заради вирішення одного питання, однієї проблеми, заради пізнання одного об'єкта або предмета. Учні переконуються в прикладному значенні своїх знань 3 предметів. Ці ж навички можуть застосуються на уроках фізики, хімії та біології. Як правило, інтегративні завдання розробляються як міжпредметні, міжциклові або такі, що зв'язують теорію і особистий досвід здобувачів освіти.

Міжпредметна проблемна ситуація - спровокований (створений) учителем стан інтелектуального утруднення учня, коли він виявляє, що для вирішення поставленого перед ним завдання, йому недостатньо наявних предметних знань i умінь, а також усвідомлює необхідність їх внутрішньої і міжпредметної інтеграції. Виділяють кілька видів і способів створення на уроці міжпредметних проблемних ситуацій, їх успішно можна застосовувати на уроках біології, хімії, фізики:

1. Ситуації несподіванки, створюються при ознайомленні учнів 3 матеріалом, що викликає подив, що вражає своєю незвичайністю.

2. Ситуації конфлікту, виникають при наявності протиріччя між: 
а) теоретично можливим способом вирішення завдання, знайденим учнями на основі своїх знань внутрішнього і міжпредметного характеру, а також неможливістю його практичного здійснення;

б) практично досягнутим результатом (відомим фактом) і недостатністю тільки предметних знань для його теоретичного обгрунтування;

в) життєвим досвідом учнів, їх побутовими поняттями і уявленнями, науковими знаннями.

3. Ситуації спростування, створюються, коли учням на основі всебічного (внутрішнього і міжпредметного) аналізу пропонують довести неспроможність будь-якого припущення, ідеї, виведення, проекту та ін.

4. Ситуації припущення, створюються, коли передбачається існування якогось явища або закону, теорії, що розходиться з отриманими раніше знаннями (внутрішнього i міжпредметного характеру), або ж потрібно довести справедливість будь-якого припущення.

5. Ситуації невизначеності, виникають, коли учням пред'являють завдання з недостатніми або надлишковими даними для отримання однозначної відповіді.

Міжпредметні зв'язки - пов'язані поля різних навчальних предметів. Вони взаємно враховують загальне між предметами, як в змісті, так і в організації освітнього процесу. Вони припускають взаємну узгодженість змісту освіти 3 різних навчальних предметів, побудову і відбір матеріалу, які визначаються як загальними цілями освіти, так і оптимальним урахуванням навчальних завдань, обумовлених специфікою кожного навчального предмета.

Міжпредметні проекти можуть виступати в ролі інтегруючих факторів в освіті, допомагаючи долати традиційну дробність і уривчастість нашої освіти.

Оскільки більшість реальних навчальних проблем носить в даний час комплексний характер, то їх рішення стає можливим лише з залученням знань 3 різних навчальних дисциплін. Причому багато хто з цих знань часто доцільно не стільки актуалізувати, скільки безпосередньо формувати в процесі вирішення цих проблем. У свою чергу, це можна здійснити лише на основі більш глибокої інтеграції, що забезпечує необхідний рівень синтезу знань здобувачів освіти. 
Інтеграція знань 3 допомогою методу проектів призводить до більш зацікавленого, особистісно значущого і осмисленого сприйняття цих знань, що підсилює мотивацію і активність залучення учнів у навчальний процес. Кожне проектно-орієнтоване завдання представляє собою тісно пов'язану ланцюжок окремих актів в діяльності школярів. Це дозволяє їм розглядати проблему проекту в різних режимах діяльності, що природним чином вимагає інтеграції знань.

Таким чином, сучасна освіта як засіб освоєння світу має забезпечувати інтеграцію предметів і різних способів пізнання світу і тим самим збільшувати творчий потенціал людини для вільних та осмислених дій, цілісного і відкритого сприйняття й усвідомлення навколишньої дійсності.

Інтеграція предметів природничого циклу в загальноосвітній школі сприяє формуванню цілісних природничо-наукових знань у здобувачів освіти, укрупнення інформаційної ємності, якщо вона здійснюється на основі системного підходу і дидактичного синтезу. Інтегроване навчання являє собою систему використання стійких міжпредметних зв'язків, властивостей, навчальних блоків, логічно i природно пов'язаних між собою в змісті споріднених предметів. Слово «інтеграція», в перекладі з латинської мови означає об'єднання в ціле будь-яких частин. Інтегрований урок - це теж об'єднання знань з різних предметів з певної теми. I воно ефективно підвищує функціональну грамотність учня, розвиває його кругозір.

Найчастіше в школі використовується термін «Міжпредметні зв'язки», які розглядають лише $з$ точки зору раціоналізації процесу навчання, економії сил $\mathrm{i}$ часу учнів, більш міцного засвоєння школярами знань 3 досліджуваних предметів. Тим часом основна задача встановлення міжпредметних зв'язків полягає в тому, щоб якісно підняти рівень знань, умінь і розвитку учнів шляхом більш глибокого проникнення в існуючі закономірні зв'язки в явищах природи і суспільства. Це перш за все, інтеграція наукових знань в теоретичних дослідженнях і практичній діяльності в школі, на уроках. 
Ступінь реалізації інтеграційних, міжпредметних зв'язків може бути різною. Це залежить від змісту теми уроку. На найпростішому рівні, використання міжпредметних зв'язків виражено в загальному констатуючому вигляді. Наступний рівень - фрагментарний. Тут міжпредметні зв'язки здійснюються в побудові навчального матеріалу у вигляді елементів, прикладів, загальних фактів, понять і складають фрагмент в структурі уроку. Вищий має на увазі органічне включення в структуру уроку навчального матеріалу з інших предметів, без яких не може бути добре і багатоаспектно вивчити новий матеріал теми, з активною участю кількох предметників. На цьому інтегративному рівні проводяться і узагальнюючі уроки, де об'єднуються знання з різних предметів 3 позиції загальних світоглядних ідей.

У таблиці 1, наведеній нижче, показана можлива інтеграція за темами навчальної програми курсів фізики, хімії та біології.

Таблиця 1.

Інтегративне навчання (фізика, хімія, біологія)

\begin{tabular}{|c|c|c|}
\hline Теми 3 фізики & $\begin{array}{c}\text { Ключові питання біології та } \\
\text { хімії, що доповнюють зміст теми }\end{array}$ & $\begin{array}{c}\text { Форма навчальної } \\
\text { діяльності }\end{array}$ \\
\hline $\begin{array}{l}\text { Тиск твердих тіл, рідин } \\
\text { i } \\
\text { газів. }\end{array}$ & $\begin{array}{c}\text { Кореневий тиск. } \\
\text { Кров'яний тиск. } \\
\text { Вплив тиску на } \\
\text { швидкість і рівновагу } \\
\text { реакції. } \\
\end{array}$ & $\begin{array}{c}\text { Рішення якісних, } \\
\text { експериментальних задач. } \\
\text { Презентація до уроку. }\end{array}$ \\
\hline Звукові хвилі. & $\begin{array}{c}\text { Природа слуху: пристрій } \\
\text { вуха, слухове сприйняття. } \\
\text { заходи попередження } \\
\text { ослаблення слуху. }\end{array}$ & $\begin{array}{c}\text { Інформація та аналіз } \\
\text { конкретних ситуацій, } \\
\text { підготовлених } \\
\text { самостійно учнями. } \\
\text { навчальний } \\
\text { проектування. }\end{array}$ \\
\hline $\begin{array}{l}\text { Механічна енергія, } \\
\text { робота, } \\
\text { потужність }\end{array}$ & $\begin{array}{c}\text { Біомеханіка м'язів, енергія } \\
\text { і потужність м'язового } \\
\text { скорочення }\end{array}$ & $\begin{array}{c}\text { Розв'язання задач. } \\
\text { Практичні завдання по } \\
\text { визначенню роботи і } \\
\text { потужності м'язів при } \\
\text { виконанні фізичних вправ. }\end{array}$ \\
\hline $\begin{array}{l}\text { Закони збереження } \\
\text { енергії }\end{array}$ & $\begin{array}{c}\text { Енергетичний обмін в } \\
\text { клітці. закони збереження } \\
\text { і перетворення енергії в } \\
\text { хімічних реакціях. } \\
\text { Витрата енергї організмом. } \\
\text { Метаболізм і фотосинтез. }\end{array}$ & $\begin{array}{c}\text { Рішення якісних, } \\
\text { експериментальних } \\
\text { завдань. }\end{array}$ \\
\hline
\end{tabular}


Продовження таблиці 1

\begin{tabular}{|c|c|c|}
\hline Теми 3 фізики & $\begin{array}{c}\text { Ключові питання біології та } \\
\text { хімії, що доповнюють зміст теми }\end{array}$ & $\begin{array}{c}\text { Форма навчальної } \\
\text { діяльності }\end{array}$ \\
\hline $\begin{array}{l}\text { Агрегатні стани } \\
\text { речовини. } \\
\text { Вологість. }\end{array}$ & $\begin{array}{c}\text { Ліпідні мембрани живої } \\
\text { клітини. }\end{array}$ & $\begin{array}{l}\text { Інформація про властивості } \\
\text { рідинно-кристалічної } \\
\quad \text { структури мембран. }\end{array}$ \\
\hline $\begin{array}{l}\text { Молекулярно- } \\
\text { кінетична теорія. } \\
\text { Основне рівняння } \\
\text { МКТ. Температура. } \\
\text { Газові закони. }\end{array}$ & $\begin{array}{c}\text { Розміри органічних і } \\
\text { неорганічних молекул. } \\
\text { Дихання рослин, тварин і людини. } \\
\text { Захист організму від } \\
\text { переохолодження. Роль шкіри в } \\
\text { терморегуляції. } \\
\text { Кругообіг води в природі. } \\
\text { Тепловий ефект реакції. }\end{array}$ & $\begin{array}{c}\text { Рішення } \\
\text { експериментальних, } \\
\text { якісних і розрахункових } \\
\text { задач. }\end{array}$ \\
\hline $\begin{array}{l}\text { Електричне поле, } \\
\text { електричний струм. }\end{array}$ & $\begin{array}{c}\text { Біопотенціали спокою і } \\
\text { дії в живому організмі. Електричні } \\
\text { поля органів. Іонізація, іонна } \\
\text { провідність } \\
\text { клітинних мембран. } \\
\text { Гідроліз сахарози, глюкози, } \\
\text { крохмалю. } \\
\end{array}$ & $\begin{array}{c}\text { Рішення } \\
\text { експериментальних задач. } \\
\text { Порівняльний аналіз з } \\
\text { природними і технічними } \\
\text { пристроями. Створення } \\
\text { узагальнюючих таблиць. } \\
\text { Навчальне проектування. }\end{array}$ \\
\hline Магнітне поле. & $\begin{array}{l}\text { Магнітне поле Землі. Власне } \\
\text { магнітне поле людини. Вплив } \\
\text { магнітних полів на організм } \\
\text { людини. } \\
\end{array}$ & $\begin{array}{c}\text { Інформація та аналіз } \\
\text { конкретних ситуацій, } \\
\text { підготовлених учнями. } \\
\text { Навчальне проектування. }\end{array}$ \\
\hline $\begin{array}{l}\text { Електромагнітні } \\
\text { коливання і хвилі. Їх } \\
\text { використання. }\end{array}$ & $\begin{array}{c}\text { Електромагнітні хвилі } \\
\text { органів людини. Вплив } \\
\text { електромагнітних хвиль на } \\
\text { людину. }\end{array}$ & $\begin{array}{l}\text { Презентація до уроку. } \\
\text { Інформація та аналіз } \\
\text { конкретних ситуацій, } \\
\text { підготовлена учнями. } \\
\text { Семінар-практикум. } \\
\end{array}$ \\
\hline $\begin{array}{l}\text { Хвильова і } \\
\text { квантова оптика. }\end{array}$ & $\begin{array}{l}\text { Природа і механізм зору. Заходи } \\
\text { попередження ослаблення зору. }\end{array}$ & $\begin{array}{c}\text { Презентація до уроку. } \\
\text { Навчальне проектування. } \\
\text { Розв'язання задач. }\end{array}$ \\
\hline Фізика атомного ядра. & $\begin{array}{c}\text { Біологічна дія випромінювань на } \\
\text { живий } \\
\text { організм. Радіоізотопний } \\
\text { метод вимірювання інтервалів } \\
\text { часу. } \\
\end{array}$ & $\begin{array}{c}\text { Семінар-практикум. } \\
\text { Рішення якісних задач }\end{array}$ \\
\hline
\end{tabular}

Реалізацію цього підходу, треба починати напочатку навчального року, узгодженням навчальних планів 3 відповідних предметів. Спочатку визначаються і формулюються теми уроків інтегрованого курсу на весь навчальний рік. Потім намічається тематика міжпредметних питань, які будуть вивчатися на уроках інтегрованого курсу. Метою яких $є$ формування поліпредметних навчальних компетенцій на основі інтеграції. 